\title{
Labour market performance and school careers of low educated graduates
}

\author{
Arjen Edzes $^{1}$ - Marije Hamersma ${ }^{1}$. \\ Viktor Venhorst ${ }^{1}$. Jouke van Dijk ${ }^{1}$
}

Received: 9 April 2014 / Accepted: 15 March 2015 / Published online: 7 April 2015

(C) The Author(s) 2015. This article is published with open access at Springerlink.com

\begin{abstract}
It is well-known that those with lower levels of education and school dropouts are less successful in the labour market. The aim of this paper is to shed light on the determinants to continue in education to at least the minimum level defined by the Lisbon Treaty 2000, the so-called starting qualification. We focus especially on the impact of the regional labour market situation and possible spill-over effects due to the presence of higher educated. In addition to that we analyze the differences in successfully finding a job between those who do and those who do not have obtained a starting qualification. We find that regional factors have a significant impact on the decision to (not) continue education and on the chance to get a job. The most striking result we found is that a prosperous regional labor market situation stimulates individuals to accept a job and dropout of school before they reach the level of the start-qualification. They seem to prefer the short term goal of earning money above an investment in schooling of which the benefits will occur in the future. We find evidence for positive spill-overs between higher and lower educated, but no evidence for negative crowding out effects. Nevertheless, personal aspects and school/education satisfaction are found to be at least as relevant in school continuation decisions and labour market outcomes of low educated school-leavers.
\end{abstract}

Keywords Human capital · Low educated · Regional labour market

JEL Classification $\quad \mathrm{C} 35 \cdot \mathrm{I} 20 \cdot \mathrm{J} 21 \cdot \mathrm{J} 31$

Arjen Edzes

a.j.e.edzes@rug.nl

1 Department of Economic Geography, Faculty of Spatial Sciences, Urban and Regional Studies Institute (URSI), University of Groningen, P.O. Box 800, 9700 AV Groningen, The Netherlands 


\section{Introduction}

In line with the Lisbon Treaty in 2000, European countries are committed to reduce the number of early school-leavers, stimulating students to at least reach a level of upper secondary education. This educational norm (the so-called start qualification) should provide the minimal basis for advanced learning and training opportunities and prepares students for successful entry into the labour market (OECD 2011: 44). Indeed, OECD figures show (2011: 116) that more education improves job prospects in general, as well as the likelihood of remaining employed in times of economic hardship.

However, the introduction of this general minimum educational norm is also disputable, because labour market prospects for low skilled persons will differ depending on the regional circumstances i.e. the sectoral and occupational structure (De Grip and Wolbers 2006), (local) labour market institutions such as employment legislation (Wolbers 2007; Bassanini and Duval 2006) and the widespread of apprenticeships as a common part of the training system (Quintini and Manfredi 2009; De Grip and Wolbers 2006). Besides these more general regional characteristics, labour market prospects of low educated may also depend on two important interaction effects with higher educated. First, low educated could suffer from crowding-out effects within the presence of medium and high skilled persons in a polarizing labour market (Gesthuizen et al. 2011; Gesthuizen and Scheepers 2010; Hensen et al. 2009). Second and conversely, they might gain from consumption externalities (Sassen 2001; Broersma et al. 2013) and could benefit from elementary jobs that arise from higher educated spending money. Because the share of higher educated is spatially concentrated these interaction effects can be seen as a typical regional characteristic. Although these regional aspects are assumed to have an effect on labour market outcomes of low educated school-leavers, their relationships have to our knowledge never been empirically studied.

The main aim of the paper is to determine the relative impact of regional characteristics alongside personal and school aspects on the choice of low educated to continue education to reach for a start qualification and, if they do not, the chance to find a job. The results can give us an insight into the necessity of general policy frameworks to prepare youngsters for a successful entry into the labour market or whether tailor made regional approaches are more suitable.

We analyse the impact of regional circumstances, such as population density, unemployment rates and the region's stock of higher educated for establishing interaction effects with higher educated. We use survey data from the Research Centre for Education and the Labour Market (ROA) for the period of 1996-2007 complemented by data from Statistics Netherlands (CBS). To study potential differences between low educated with and without a 'start qualification' i.e. the minimal required education for a successful career, we run separate analyses for both groups.

The outline of our article is as follows. In Sect. 2 we provide a theoretical framework. In Sect. 3 we will describe the dataset. In Sect. 4 we will present our empirical results followed by concluding remarks in Sect. 5. In brief, we find regional circumstances to be relevant in explaining the choice to continue education, especially for the ones without a start qualification. In explaining the chance to find a job, regional factors 
are relevant for both those below and above the educational norm. We find positive (spill-over) effects of the presence of higher educated on the chance to find a job for the lower educated graduates, however were not able to identify crowding out effects or effects on the choice to continue education. Hence, our results provide indications for the added value of regional specific variation to labour market policy.

\section{Theoretical background}

Several studies have confirmed that especially low-educated people are vulnerable, showing lower labour force participation rates, lower earnings and facing inferior working conditions compared to higher educated workers (e.g. Gesthuizen and Scheepers 2010; Layte et al. 2001; Tsakloglou and Papadopoulos 2002; Muffels and Fouarge 2004). Following human capital theory (e.g. Becker 1964), chances on the labour market improve with an increase of education. There is indeed an overwhelming empirical literature showing that investment in education leads to better job opportunities and higher wages (e.g. Broersma et al. 2013; Ashenfelter et al. 1999; Psacharopoulus and Patrinos 2002; Gesthuizen and Scheepers 2010). Consequently, in most modern western economies the policy aim is to stimulate low educated school participants to continue education to the highest possible level (OECD 2011).

However, in the meantime, there are also large regional disparities in socioeconomic positions and unemployment rates of low educated, leading to the question whether national programs to stimulate educational attainment is the right thing to do. Lopez-Bazo and Motellon (2012) find for Spain for instance that only a part of the regional gap in unemployment rates can be explained by the spatial distribution of observed individual and household characteristics, like education. Instead, they find that Spain's regions differ in the impact that these characteristics can have on the probability of being unemployed in a given region. Gobillon et al. (2011) find for France that $30 \%$ of the spatial disparities are explained by individual characteristics, the rest is explained by local indicators, mainly correlated with regional segregation. Machid et al. (2011) focus on the lack of labour mobility of low educated that hinders the levelling of regional labour markets.

One important but neglected issue in the literature thus far is the relation between the chances of low educated and the stock of higher educated in the region and the changing occupational structure. Labour markets are polarizing with the share of manually- and elementary jobs on the one hand and higher- and scientific jobs on the other hand staying constant or even rising, while the share of low- and medium skilled jobs is declining (e.g. Oesch and Rodríques Menés 2011; Autor et al. 2006, 2003; Spitz-Oener 2006; Goos and Manning 2007). This development is well documented in western economies. For the Netherlands Josten (2010) shows that although the number of low educated persons has been declining in recent years, the number of elementary skilled jobs is rather stable. That, in spite of the developments in the changing levels of jobs, the position of low educated is worsening, is according to this reasoning attributed to crowding-out effects of low skilled by medium- and high skilled (Gesthuizen and Scheepers 2010; Hensen et al. 2009). Higher educated could crowdout low educated especially when there is an oversupply in relation to the demand on 
the local labour market (Gesthuizen and Wolbers 2010). In contrast, low educated can also benefit from a high share of high educated in a region by so-called consumption externalities, i.e. the spending power of high educated or high skilled inhabitants (not necessarily only workers) has a positive effect on the income of inhabitants with a lower education or on a lower skilled job (Sassen 2001; Broersma et al. 2013). Consumption externalities raise the income of these low educated through a demand effect: extra employment requiring low skills is created by demand from high educated individuals. This is in particular true when consumption of higher educated causes a demand for low skilled jobs, for instance in the personal service industry and in the hotel- and catering industry. As well, if the productivity of a region increases by the presence of higher educated, this could create new jobs from which low educated could benefit (Broersma et al. 2013; Moretti 2004a, b).

In our empirical analyses, we will explore the relative importance of these regional characteristics in the choice to continue education or find a job for low educated schoolleavers in the Netherlands. We expect the educational choices and job chances for low educated to be influenced by regional characteristics (e.g. Broersma et al. 2013; De Grip and Wolbers 2006). More specifically, both may be influenced by the demand for low skilled and the unemployment level at a regional scale. A high number of elementary jobs or a positive regional business cycle would pull low educated to the labour market whereas high unemployment would stimulate continuing education. As well, we explore potential consumption externalities and crowding out effects in the interaction of lower educated graduates with higher educated working and/or residing in regions (Gesthuizen and Scheepers 2010; Hensen et al. 2009; Broersma et al. 2013; Sassen 2001). The outcomes may vary over regions because higher educated concentrate predominantly in urban and population dense areas, especially in the period following their graduation from institutions of higher education (Venhorst et al. 2011).

We will study the influence of regional characteristics alongside personal and school characteristics. We include personal characteristics from which we know from the literature that they influence the educational choices, job search behaviour and labour market outcomes, such as gender, ethnicity, age and field of study (see for instance Tieben and Wolbers 2010; van der Meer 2008). School factors are included as studies concerning early school leaving mention the importance of the school environment in the decision to premature leaving education (for an overview of research, see e.g. Prevatt and Kelly 2003). Perceived school quality can therefore be a stimulus in continuing education. Besides that a proper education of a good quality might positively influence a student's position on the labour market. In our analysis we will reflect on their relative importance compared to regional characteristics.

\section{Data and method}

\subsection{Dataset used}

We used a dataset from the Research Centre for Education and the Labour Market (ROA). The dataset is based on a representative group of school leavers in the Netherlands, who were asked to fill in a survey approximately 18 months after finalizing 
their education, covering school-leaver-cohorts from 1996-2007. With the survey, demographics, information about the finished education and about the current activity at moment of survey (i.e. being in higher education, (un)employed or not-active) is gathered on a cross-sectional base.

As we focus on the low educated school leavers, we selected respondents who finished an education in pre-vocational secondary education (in Dutch: VMBO) or in the first two levels of secondary vocational education (in Dutch: MBO level 1 or 2). In the latter group we can distinguish between those with a vocational training (4 days at school, 1 day at work) and those with an apprenticeship training (1 day at school, 4 days at work). We focus on all graduates between the age of 15 and 30 approximately 1.5 years after receiving their diploma.

Within the selected group we distinguished between the ones with 'no start qualification' i.e. received their diploma on either pre-vocational secondary education (VMBO) or the first level of secondary vocational education (MBO 1) and the ones who reached the 'start qualification' level i.e. received their diploma on the 2 nd level of secondary vocational education (MBO 2). This 'start qualification' is comparable with the European Lisbon norm as the minimum educational level that people should attain before they leave school. Consequently each respondent is classified in a group based on the current activity at the time of survey. We distinguish between four categories; either someone is (1) participating in further education, (2) employed for at least $12 \mathrm{~h}$, (3) unemployed (or working less than $12 \mathrm{~h}$ ) or (4) not classified in any of the groups (assumed not to participate). Figure 1 visually describes the classification process.

\subsection{Variables in the dataset}

For each respondent, the dataset contains information on basic personal demographics (gender, age, nationality and the cohort year), field of education and level of education as well as -more school related- educational experiences (i.e. education satisfaction), which were used as explanatory variables in our model. Regarding the latter, we added a variable in which school leavers were asked whether they would choose the same education, a different education or would choose not to study at all when they would be able to start over again. In this we assume that people who indicate to choose the same education again are more satisfied with the followed education. As we do not have this information available for all respondents, we added a category 'satisfaction unknown' to our models.

\subsection{Regional variables}

Regional information was linked to each respondent based on the year and the residential location at the moment of survey. The regional data used come from Statistics Netherlands for the period of 1997-2008 on 18 regions at the RBA-level. ${ }^{1}$ In our

1 The RBA (Regionale Bureaus Arbeidsvoorziening) area is a classification of the Netherlands originating from the 1990's. 


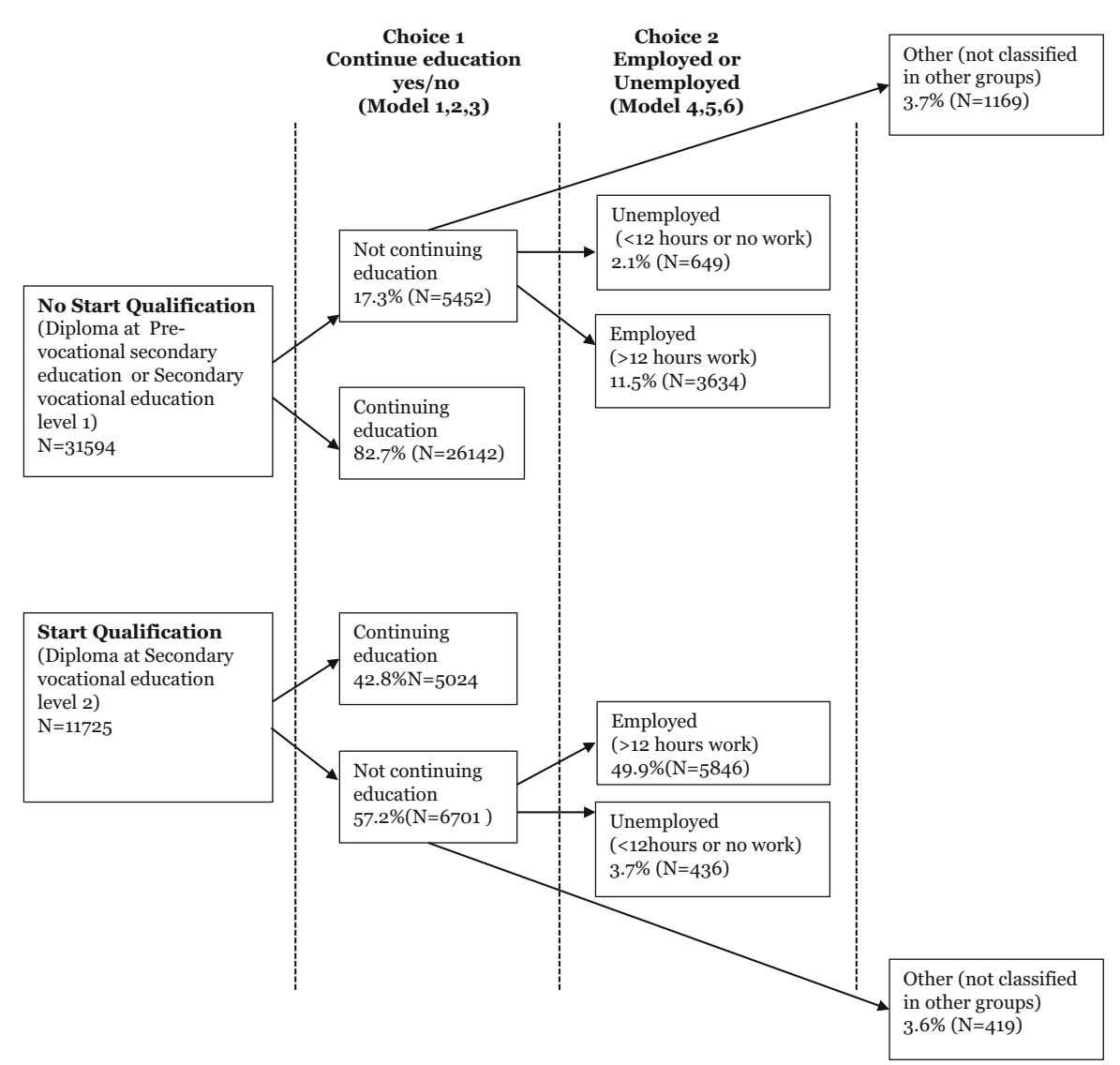

Fig. 1 Classification in groups

selection of explanatory regional variables, we checked for multi-collinearity issues by inspecting correlations and the verification of inflation factors (VIF) of the model (e.g. Hair et al. 2006). Based on the outcomes of this check the following regional variables were included. Regional unemployment is measured by the percentage of unemployment under young people (15-25) in the region. Population density is included to measure urbanity. The number of working people with an elementary or lower profession is added as an indication of total absolute labour demand for low educated. We included regional economic growth (added value) as we are interested in the effect of the business cycle on the position of low educated graduates. To explore whether the choice to continue education or the chance to find work is related to the presence of high educated in the region, we added two additional variables. To capture possible crowding-out effects of the higher educated on lower educated graduates, we calculated the regional oversupply of high educated by dividing the share of working people with a high education by the share of high skilled jobs. Regional productivity or consumption spill-overs is captured by the percentage of higher educated living within the area. Appendix A shows per RBA-region the average value for the regional variables we include in the model. 


\subsection{Empirical approach}

In the first analysis we perform a binary logistic regression analysis with the choice to continue in further education (1) versus not continuing further education (0) as a dependent variable. We estimate separate models for those having or not having a 'start qualification' to see whether we find differences between both groups of low educated (see also Fig. 1). In the base model (M1) we start with including general regional characteristics based on the residential location of the graduates together with their demographic- and educational characteristics. In a second model (M2) we add the presence of higher educated and in the third model (M3) we explore the relationship with school/educational satisfaction. The stepwise approach is chosen to check the robustness of results.

In the second analysis we make a selection of school-leavers who decide to enter the labour market (group 'employed' and 'unemployed' in Fig. 1) and analyze the chance to be 'employed' (1) versus being 'unemployed' (0). Again we estimate separate models for those having or not having a 'start qualification'. We use the same stepwise approach for the model estimation. In the basic model (M4) we included only our general demographic, educational and regional controls, in the next step we included the interaction with higher educated in the model (M5) and we finally included in the model (M6) the variable for educational satisfaction.

\section{Results}

\subsection{Decision to continue in further education}

The first analysis focuses on the decision to (dis)continue education. The descriptives for this analysis can be found in Appendix B. As we can extract from Fig. 1 almost $83 \%$ of the graduates without a 'start qualification' choose to continue education, while for those with a 'start qualification' the percentage is almost $43 \%$.

The estimation results are presented in Table 1. Concerning the regional effects we can observe a difference between graduates with and without 'start qualification'. For the former, the effect of region in explaining educational choice is far more marginal. The lowest educated without a 'start qualification' seem to base their educational decision more on the attractiveness of the labour market. In a prospective economic situation, within more population dense areas (with more jobs available), in areas with low unemployment and many low skilled jobs, there is a significantly higher chance for graduates without a 'start qualification' to discontinue education within the period of research. For the group with a 'start qualification', we only find a stable negative effect for population density, meaning that lower educated with a 'start qualification' are more likely to discontinue education in population dense areas. Furthermore, our results show no indication that consumption externalities or crowding out effects by the presence of higher educated in the region affect the decision to continue in education for both groups of low educated.

With respect to personal factors we find that females quit education more often, but only if they reached their start qualification. Elderly youngsters and natives quit edu- 


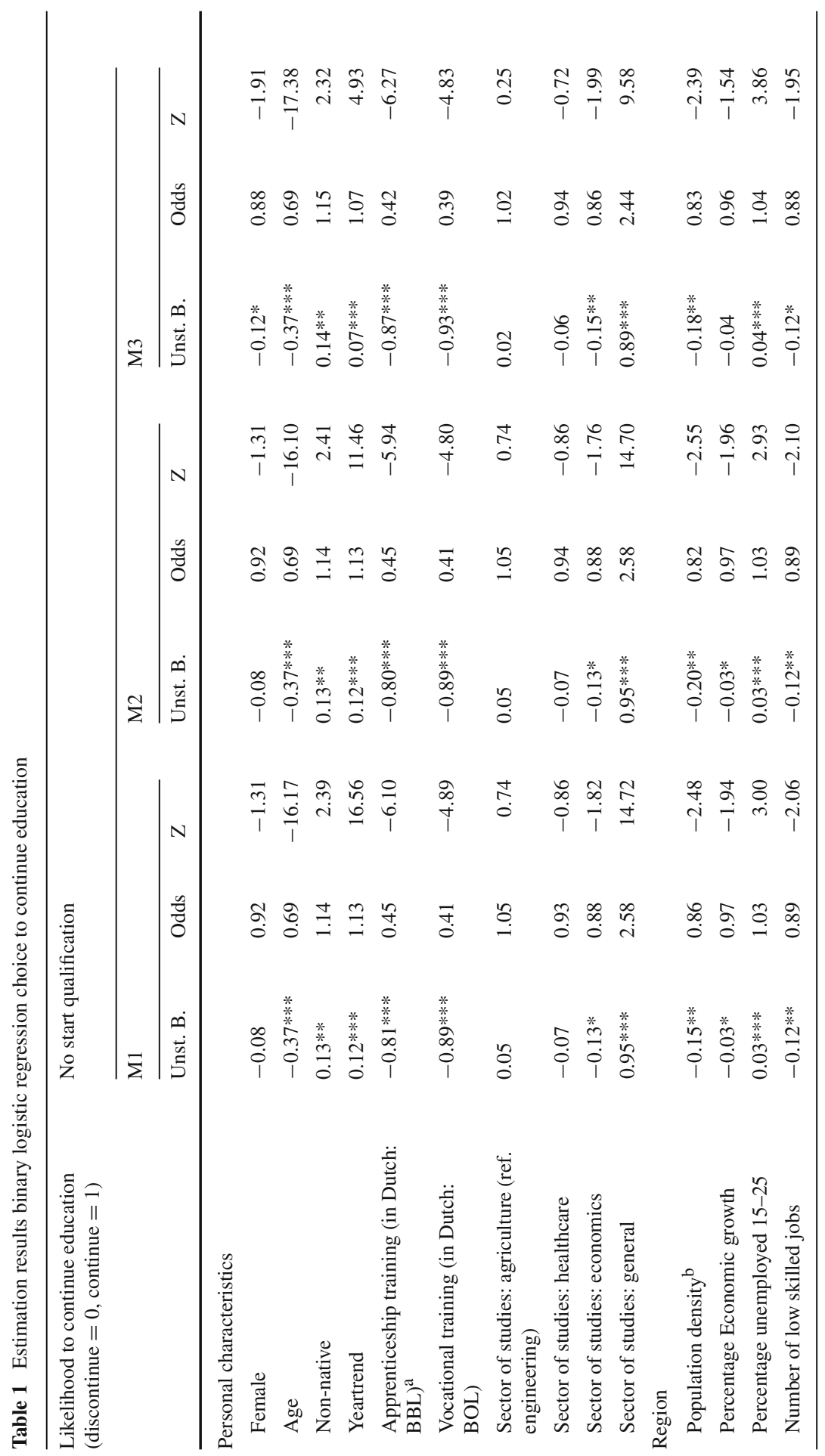




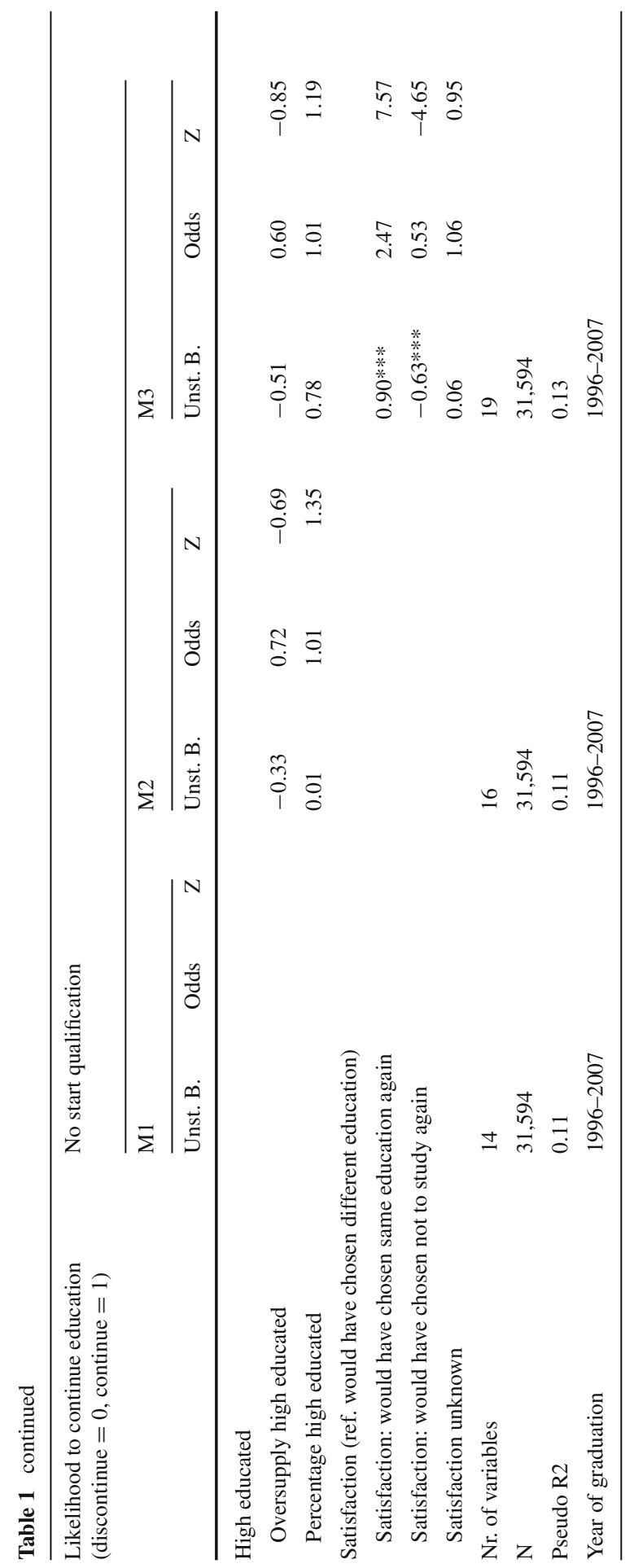




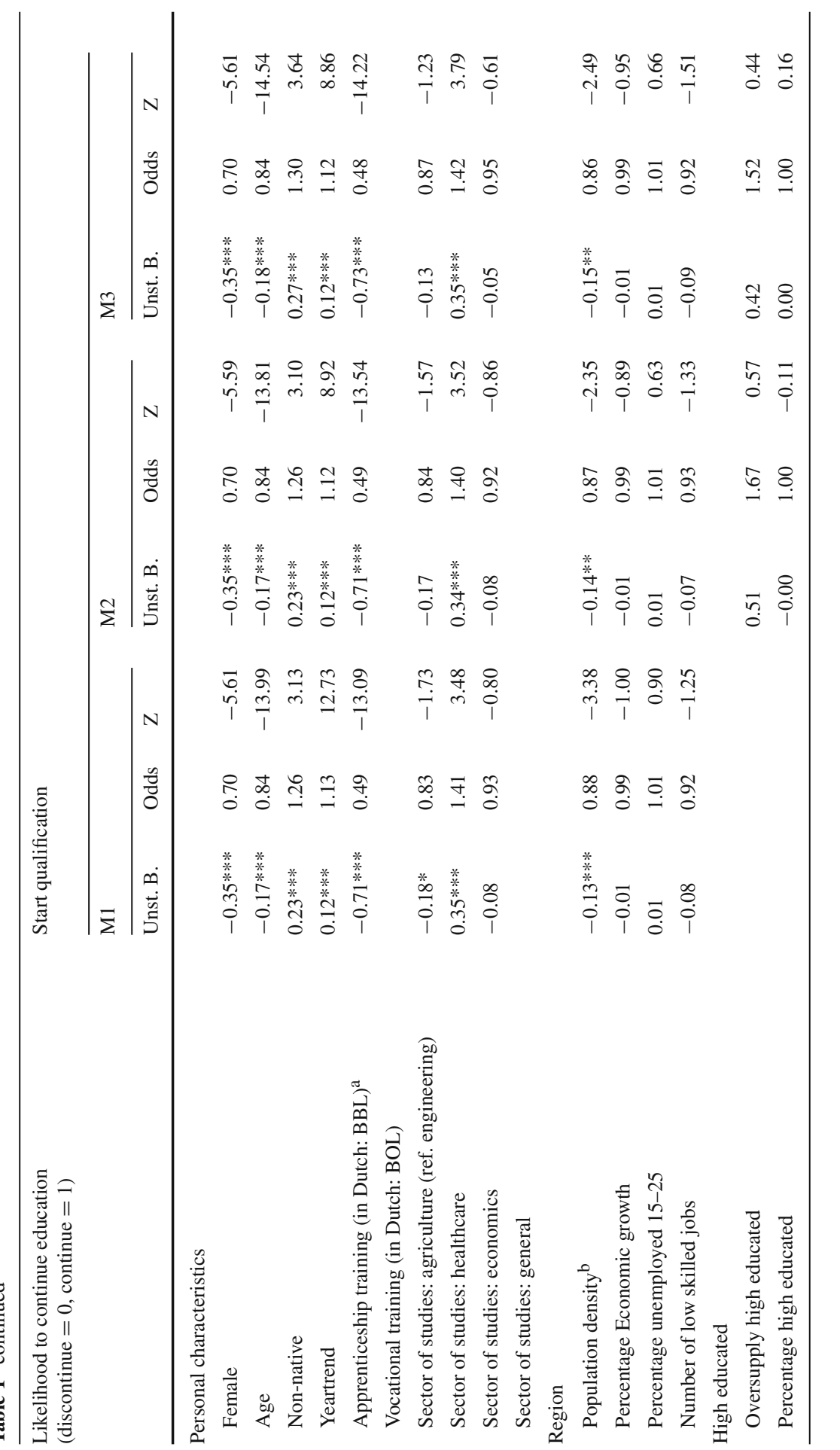




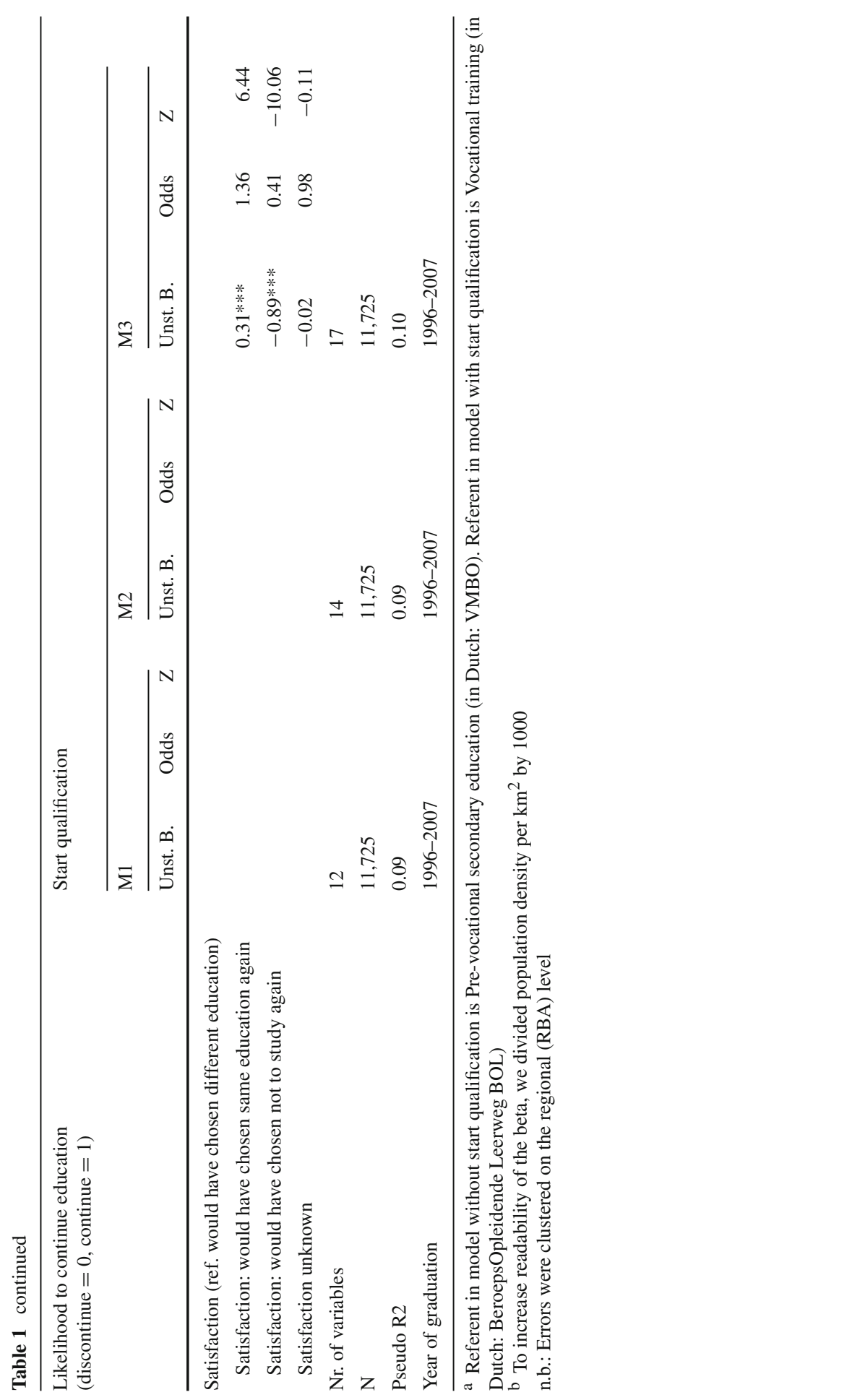


cation more often, in both groups with and without a start qualification. The yeartrend shows that over the years school graduates continue education more often reflecting that the general trend of the increasing educational attainment also applies to lower educated. Both apprenticeships- as vocational training quit education more often compared to students with only pre-vocational secondary education (in Dutch: VMBO). Once they reached their start qualification, participants in apprenticeship training quit education more often. School participants in general sectors of study continue education more often if they haven't reached their start qualification yet; after having a start qualification mainly students in healthcare related studies continue education.

Finally, with respect to school/education characteristics, a strongly significant relation is found between education satisfaction and the decision to continue education, especially for graduates without a 'start qualification'. Graduates indicating to choose the same study and school again when they could start over, are more likely to participate in further education. However, we have to be careful with this conclusion because reverse causality might play a role here: the current situation of being in an education or not could influence the ex-post evaluation of the previous education, and vice versa.

\subsection{Chance to find a job}

In the second analysis we model the chance to find a job versus being unemployed for those who quit education and enter the labour market. The descriptive statistics can be found in Appendix C. As we can extract from Fig. 1, from each graduate who decided to enter the labour market, about 1 in 5 without a 'start qualification' is unemployed 18 months after graduation, for those with a 'start qualification' this is almost 1 in 14. It is clear that those without a starting qualification have a twice as high risk of unemployment.

Table 2 shows the estimation results of the binary logistic models. Concerning the regional characteristics, we find comparable effects for both groups in explaining the chance to find a job. In line with expectations, the chance to get a job is positively influenced by economic growth and smaller in areas and time periods with more unemployment. In the base model (M4) we do not find an effect of the number of low skilled jobs in the area or the population density for any of the groups. Nevertheless both variables become significant when we include the variables indicating the presence of high educated in the area (M5). We find a positive effect of the percentage of higher educated living in the area on the chances to find a job for both of the groups. It seems that the presence of higher educated living in an area has a positive effect on job opportunities in the area for the low skilled. Our operationalization does not allow for a clear distinction of either productivity or consumption spill-overs, but given the fact that we are looking at the effect of the higher educated residing in these regions, it appears likely that these are predominantly consumption spill-overs. It is interesting to see that with the inclusion of this variable, the effect of population density turns to negatively significant for both groups. This suggests that initial effects of density and job supply seem to be mediated by the presence of higher educated in these regions. The oversupply effect of higher educated on the job chances of lower educated is however not found to influence the chance to find a job for either of the groups. For 


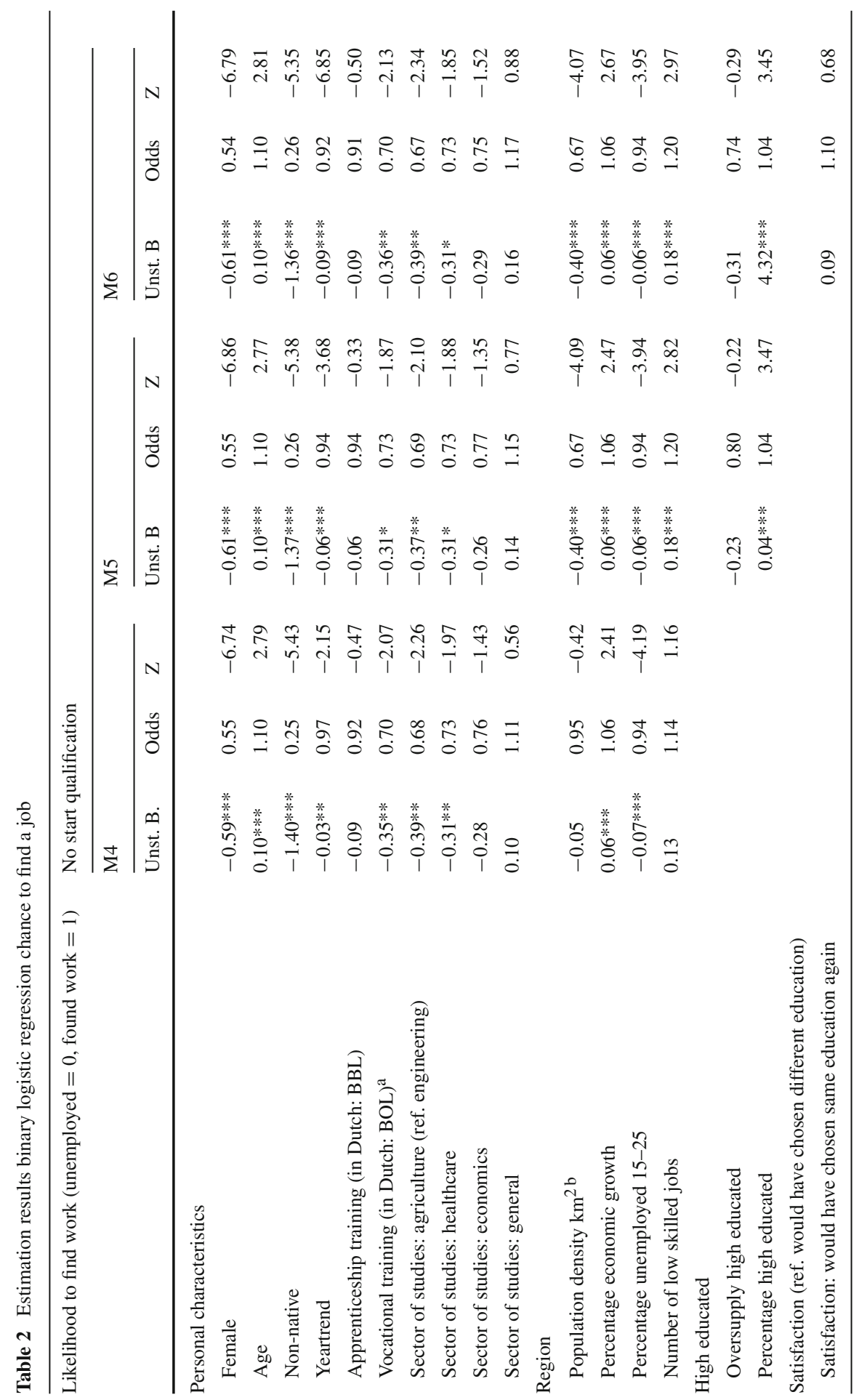




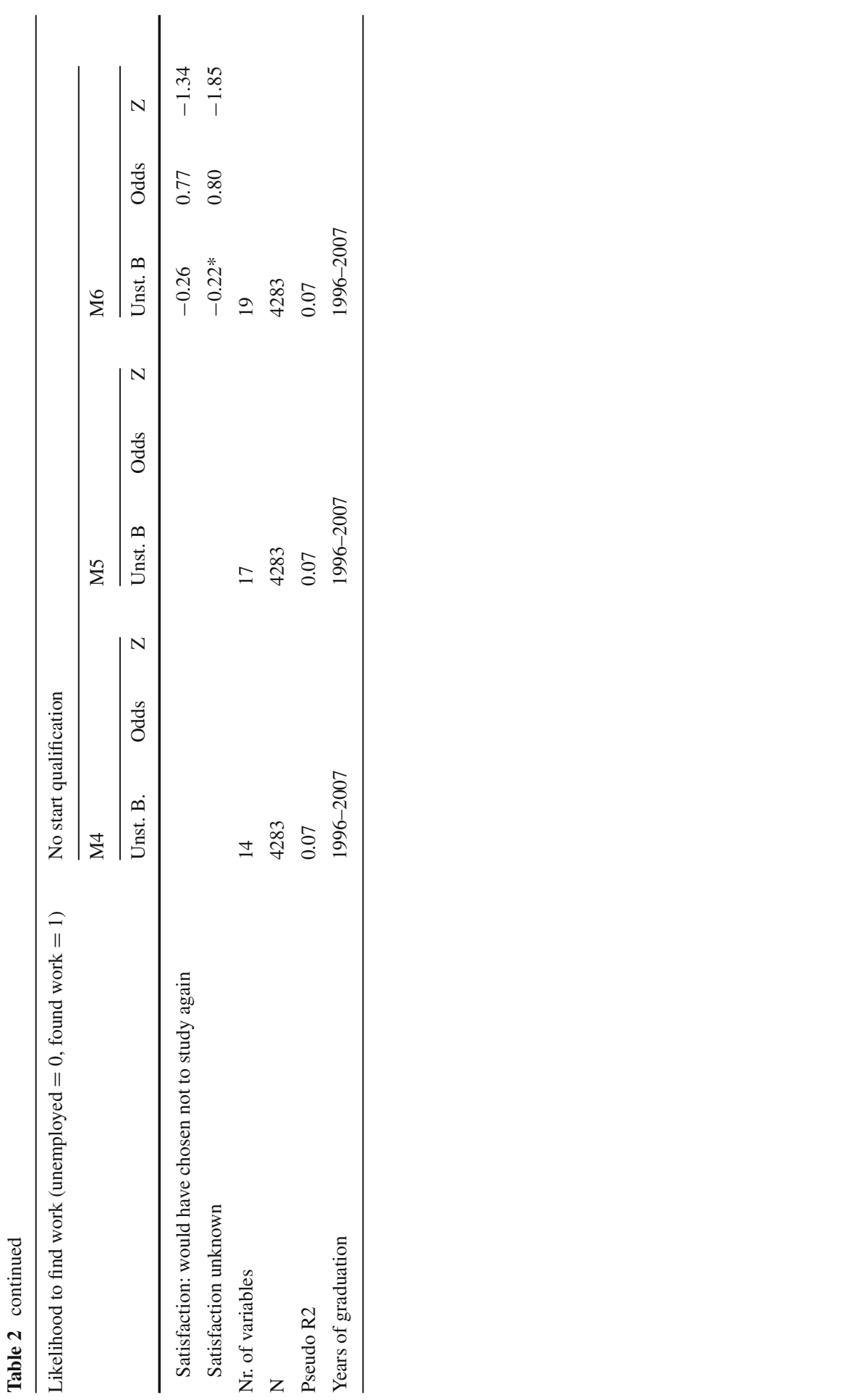




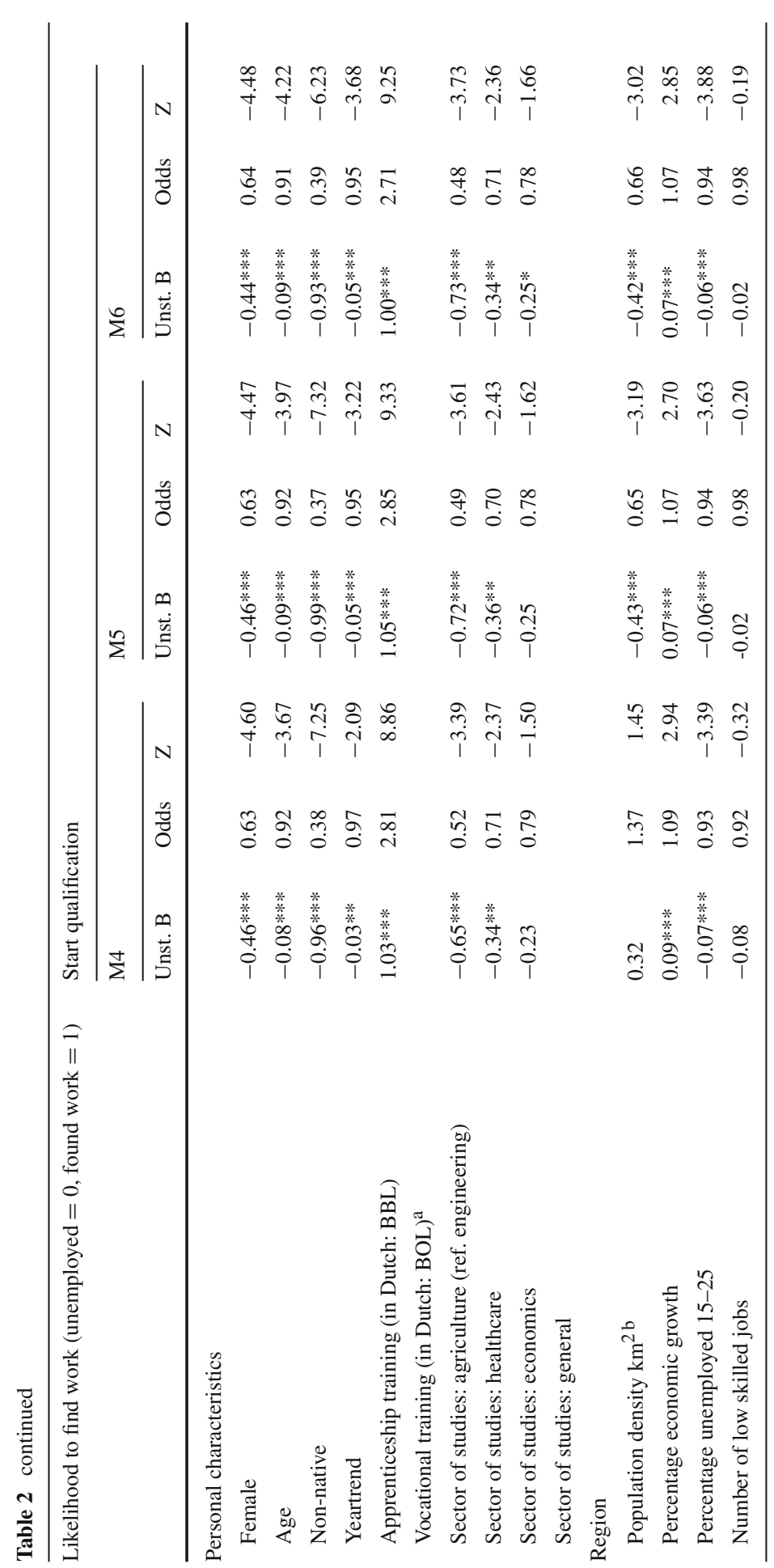




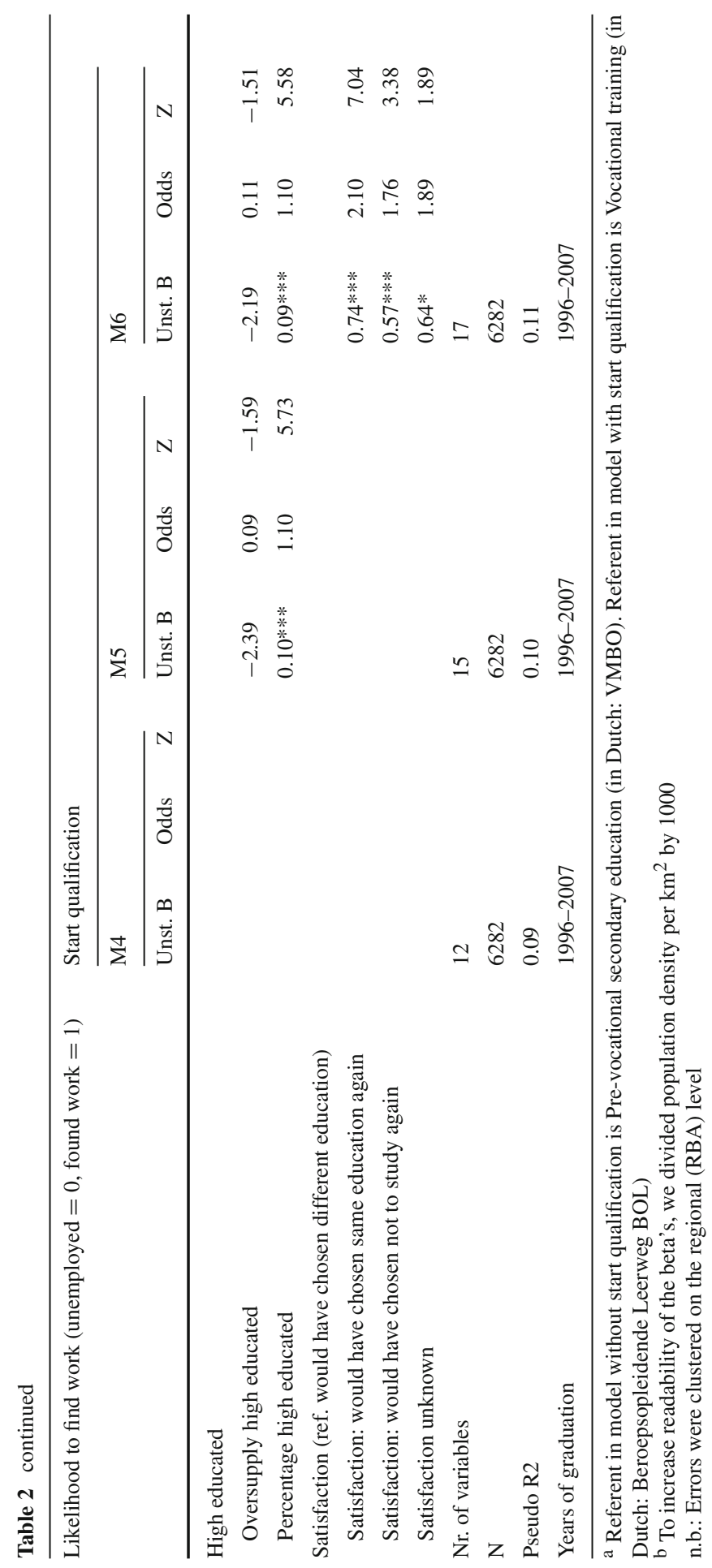


the ones without a start qualification, the number of low skilled jobs in the region turns positively significant in explaining the chance to find a job after inclusion of the presence of higher educated. Regardless of the presence of higher educated, job changes of low educated are higher when there are many low skilled jobs.

With regard to personal characteristics, we find a strongly negative effect on the chance to find a job for women and immigrants, especially within the group without a 'start qualification'. Besides we find for the group without a 'start qualification' a higher chance for older graduates, and for those with a 'start qualification' a lower chance for older graduates to find a job. So, more life experience compensates most likely only for jobs requiring very few skills. We find a negative trend effect meaning that the chance to find a job has deteriorated a little bit over the years 1996-2007. Graduates who decide to enter the labour market with a vocational training on level 1 have a lower chance to find a job than the ones with a pre-secondary vocational education. For those with a 'start qualification' we find a positive effect on the chance to find a job for graduates with apprenticeship training compared to vocational training. For both groups, people with an agricultural or healthcare education have a smaller chance to find a job compared to people with a technical education.

The inclusion of the school/education satisfaction variables in model has little effect on the regional effects reported and only results in a significant impact on graduates with a 'start qualification'. Interesting is that both, those who indicate they would choose the same education again as those who indicate not to study again, have a better chance to find a job compared to graduates who would have chosen a different education. We assume the most satisfied graduates are more motivated and dedicated to their field of study and therefore have a better chance to find a job. It might also be that satisfaction tells us something about school quality and that the most satisfied therefore have the most capabilities and the best chances on the labour market. Instead, the ones who indicate that they would have chosen another education (the referent) might have more difficulties in finding a satisfying job. Again, reverse causality might also play a role here, with the fact that a job was found based on the educational program influencing the ex-post evaluation of that program, and vice versa. Graduates indicating not to study again are probably eager to earn money instead of learning more and therefore might be less demanding in accepting a job they can get.

\section{Summary and conclusion}

The position of lower educated on the labour market has been found to be rather weak in many empirical studies. Therefore, in many countries policy measures to stimulate longer periods of enrollment in education are in operation with the goal that everyone should reach the minimum level of education to be successful on the labour market. This is the so-called 'starting qualification' accepted by the Lisbon Treaty in 2000. However, empirical evidence about the determinants to continue education is still scarce, especially with regard to the impact of the regional labour market situation.

In this paper we explored the likelihood that young recent low educated graduates invest in further education. Also, we looked at the determinants of initial labour market success, measured as being in paid employment 18 months after graduation. 
We explicitly investigated the impact of regional circumstances, with a special attention to the effect of spill-overs and crowding-out effects resulting from presence of higher educated in regions. These circumstances, external to the individual graduate are playing an important role in a graduate's assessment of the added value of spending extra time in school. Furthermore we controlled for personal characteristics as well as explored associations with school/educational satisfaction. Throughout the analysis we distinguished between low educated with as highest completed grade below or above the minimum educational norm ('start qualification'), which is the international standard for entering the labour market. In addition, we also tested to what extent school-leavers who leave the education system below this minimum norm have a higher chance to become unemployed.

Concerning the choice to continue education, we found that especially lower educated graduates without a 'start qualification' seem to base their decisions to quit school on the labour market opportunities. For the period under investigation, we found that a higher population density, more economic growth and a higher number of low skilled jobs in their residential region stimulates this group of graduates to discontinue education, while a higher regional youth unemployment rate encourages them to continue education. For those with a 'start qualification' only population density significantly leads to more discontinuation in education. We found no indications that the choice to continue education is affected by by the presence of more higher educated in their residential area.

When we look at the economic outcomes in terms of job chances, we found that the impact of regional characteristics is of comparable importance for both groups of low educated graduates. Regional unemployment deteriorates, while economic growth stimulates the chances to find a job. Furthermore low educated have a better chance to find a job when there are many low skilled jobs available. Concerning the presence of higher educated we found that job chances for low educated are better in areas where a lot of high educated people live, which may be due to a consumption spill-over. However, no clear crowding-out effects were found; chances of lower educated do not seem lower when there is an oversupply of higher educated compared to the number of high skilled jobs. This might indicate that the lowest jobs on the labour market are not in competition with higher educated. Further research is needed to better understand this interrelationship.

Overall our analyses showed that regional circumstances indeed have a significant influence on the choices of low educated to continue in education as well as on their success to find a job. Nevertheless, it appeared from our analyses that these regional labour market circumstances are not the most important factors. Individual characteristics are frequently found to be at least as important, if not more important. We also found strong effects for the school/education satisfaction measures, but these results need to be interpreted with care, as reverse causality might play a role here.

To come back to the question we raised, what kind of policy works best to improve positions of low educated school-leavers? Our findings indicate that to improve the economic position of low educated, a combined manner of more national and regional specific policy would be most fruitful. On the national level first of all the policy should be aimed to facilitate for each individual to reach the maximum level of education. In addition to that, specific groups of low educated students such as non-natives and 
women, need attention because they may drop out for other reasons than not having the cognitive skills to complete a higher level of education. As well, investments into educational quality seem worthwhile, because our results indicate that this has a positive effect on continuation of enrollment, although the results of our research need to be further verified by additional research. On the regional level, especially efforts should be taken to provide chances for low educated in weaker economic regions after they finished the highest possible level of education in order to enhance their chances to find a job. However, in regional labor markets with attractive circumstances and easy access to jobs, this may prevent that youngsters complete education till the level of the 'starting qualification' because the short term gains of earning money dominate the choice for investing in education of which the benefits occur in the long run. For this group a policy aiming at the (obligatory) continuation in school may in the long run be beneficial for as well this group as for society as a whole.

Open Access This article is distributed under the terms of the Creative Commons Attribution License which permits any use, distribution, and reproduction in any medium, provided the original author(s) and the source are credited.

\section{Appendix A: Regional variables}

See Table 3 .

Table 3 Average of regional variables by RBA-region of residence (1997-2008)

\begin{tabular}{|c|c|c|c|c|c|c|}
\hline RBA region & $\begin{array}{l}\text { Percentage } \\
\text { Economic } \\
\text { growth }(\%)\end{array}$ & $\begin{array}{l}\text { Percentage } \\
\text { unemployed } \\
15-25(\%)\end{array}$ & $\begin{array}{l}\text { Population } \\
\text { density km² } \\
(\times 1000)\end{array}$ & $\begin{array}{l}\text { Number of } \\
\text { low skilled } \\
\text { jobs }(\times 1000)\end{array}$ & $\begin{array}{l}\text { Oversupply } \\
\text { high educated }\end{array}$ & $\begin{array}{l}\% \text { High edu- } \\
\text { cated in area } \\
(\%)\end{array}$ \\
\hline Groningen & 5 & 14 & 0.24 & 77 & 1.04 & 28 \\
\hline Friesland & 6 & 14 & 0.19 & 85 & 0.97 & 21 \\
\hline Drenthe & 6 & 10 & 0.18 & 66 & 0.89 & 20 \\
\hline $\begin{array}{l}\text { IJssel- } \\
\text { Vecht/Twente }\end{array}$ & 6 & 8 & 0.32 & 144 & 0.93 & 22 \\
\hline IJssel/Veluwe & 6 & 6 & 0.33 & 114 & 0.95 & 25 \\
\hline $\begin{array}{l}\text { Arnhem-Oost } \\
\text { Gld./Nijm. } \\
\text { Rivierenland }\end{array}$ & 6 & 9 & 0.44 & 167 & 0.99 & 28 \\
\hline Flevoland & 9 & 9 & 0.23 & 46 & 0.88 & 23 \\
\hline $\begin{array}{l}\text { Midden- } \\
\text { Nederland }\end{array}$ & 6 & 7 & 0.87 & 163 & 1 & 37 \\
\hline $\begin{array}{l}\text { Noord-Holland } \\
\text { Noord }\end{array}$ & 6 & 7 & 0.43 & 84 & 0.92 & 23 \\
\hline $\begin{array}{l}\text { Zuidelijk } \\
\text { Noord-Holland }\end{array}$ & 6 & 11 & 1.54 & 211 & 1.02 & 35 \\
\hline Rijnstreek & 6 & 6 & 0.96 & 99 & 0.94 & 30 \\
\hline Haaglanden & 6 & 8 & 2.37 & 119 & 0.99 & 35 \\
\hline
\end{tabular}


Table 3 continued

\begin{tabular}{lllllll}
\hline RBA region & $\begin{array}{l}\text { Percentage } \\
\text { Economic } \\
\text { growth }(\%)\end{array}$ & $\begin{array}{l}\text { Percentage } \\
\text { unemployed }\end{array}$ & $\begin{array}{l}\text { Population } \\
\text { density } \mathrm{km}^{2}(\%) \\
(\times 1000)\end{array}$ & $\begin{array}{l}\text { Number of } \\
\text { low skilled } \\
\text { jobs }(\times 1000)\end{array}$ & $\begin{array}{l}\text { Oversupply } \\
\text { high educated }\end{array}$ & $\begin{array}{l}\% \text { High edu- } \\
\text { cated in area } \\
(\%)\end{array}$ \\
\hline Rijnmond & 6 & 10 & 1.02 & 217 & 0.91 & 24 \\
Zeeland & 5 & 8 & 0.23 & 61 & 0.94 & 21 \\
$\begin{array}{l}\text { Midden- en } \\
\quad \text { West-Brabant }\end{array}$ & 6 & 8 & 0.49 & 147 & 0.98 & 25 \\
$\begin{array}{l}\text { Noordoost- } \\
\quad \text { Brabant }\end{array}$ & 8 & 5 & 0.45 & 95 & 0.98 & 25 \\
$\begin{array}{l}\text { Zuidoost-Brabant } \\
\text { Limburg }\end{array}$ & 6 & 8 & 0.50 & 102 & 1.03 & 29 \\
\hline
\end{tabular}

\section{Appendix B}

See Table 4.

Table 4 Descriptives model choice to continue education

\begin{tabular}{|c|c|c|c|c|c|c|c|c|}
\hline & \multicolumn{4}{|c|}{ No 'start qualification' } & \multicolumn{4}{|c|}{ 'Start qualification' } \\
\hline & Mean/pct & Std dev & Min & $\operatorname{Max}$ & Mean/pct & Std dev & Min & $\operatorname{Max}$ \\
\hline \multicolumn{9}{|l|}{ Demographics } \\
\hline Age & 18 & 1.10 & 16 & 30 & 21 & 2.09 & 16 & 30 \\
\hline Male & $45 \%$ & & & & $54 \%$ & & & \\
\hline Immigrant & $12 \%$ & & & & $12 \%$ & & & \\
\hline \multicolumn{9}{|l|}{ Sector of studies } \\
\hline General & $31 \%$ & & & & $0 \%$ & & & \\
\hline Agriculture & $31 \%$ & & & & $13 \%$ & & & \\
\hline Engineering & $13 \%$ & & & & $33 \%$ & & & \\
\hline Economics & $12 \%$ & & & & $37 \%$ & & & \\
\hline Healthcare & $13 \%$ & & & & $17 \%$ & & & \\
\hline \multicolumn{9}{|l|}{ Level of education } \\
\hline $\begin{array}{l}\text { Pre-vocational secondary } \\
\text { education }\end{array}$ & $95 \%$ & & & & $0 \%$ & & & \\
\hline $\begin{array}{l}\text { Secondary vocational education } \\
\text { level } 1\end{array}$ & $5 \%$ & & & & $0 \%$ & & & \\
\hline $\begin{array}{l}\text { Secondary vocational education } \\
\quad \text { level } 2\end{array}$ & $0 \%$ & & & & $0 \%$ & & & \\
\hline \multicolumn{9}{|l|}{ Category of studies } \\
\hline $\begin{array}{l}\text { Pre-vocational secondary } \\
\text { education }\end{array}$ & $95 \%$ & & & & $0 \%$ & & & \\
\hline Vocational training & $3 \%$ & & & & $58 \%$ & & & \\
\hline Apprenticeship training & $2 \%$ & & & & $43 \%$ & & & \\
\hline
\end{tabular}


Table 4 continued

\begin{tabular}{|c|c|c|c|c|c|c|c|c|}
\hline & \multicolumn{4}{|c|}{ No 'start qualification' } & \multicolumn{4}{|c|}{ 'Start qualification' } \\
\hline & Mean/pc & t Std dev & Min & $\operatorname{Max}$ & Mean/pc & t Std dev & Min & $\operatorname{Max}$ \\
\hline \multicolumn{9}{|l|}{ Region } \\
\hline Population density $\quad \mathrm{km}^{2}(x 1000)$ & 0.70 & 0.49 & 0.17 & 2.46 & 0.6 & 0.45 & 0.17 & 2.46 \\
\hline Percentage economic growth & $5.2 \%$ & 2.6 & $-3.1 \%$ & $13.1 \%$ & $5.7 \%$ & 2.4 & $-3.1 \%$ & $13.1 \%$ \\
\hline Percentage unemployed $15-25$ & $9.5 \%$ & 3.5 & $1.0 \%$ & $25.1 \%$ & $9.4 \%$ & 3.6 & $1.0 \%$ & $25.1 \%$ \\
\hline $\begin{array}{l}\text { Number of working people } \\
\text { with an elementary or } \\
\text { lower job (x1000) }\end{array}$ & 142.7 & 57.1 & 36.0 & 232.4 & 135.7 & 52.3 & 36.0 & 232.4 \\
\hline \multicolumn{9}{|l|}{ High educated } \\
\hline Oversupply high educated & 0.90 & 0.08 & 0.80 & 1.20 & 0.9 & 0.07 & 0.8 & 1.20 \\
\hline Percentage high educated & $27.1 \%$ & 5.8 & $16.7 \%$ & $42.1 \%$ & $26.0 \%$ & 5.5 & $16.7 \%$ & $42.1 \%$ \\
\hline \multicolumn{9}{|l|}{ Satisfaction } \\
\hline Choose same education & $51 \%$ & & & & $68 \%$ & & & \\
\hline Choose different education & $11 \%$ & & & & $23 \%$ & & & \\
\hline Not study at all & $1 \%$ & & & & $7 \%$ & & & \\
\hline Satisfaction unknown & $37 \%$ & & & & $2 \%$ & & & \\
\hline \multicolumn{9}{|l|}{ Dependent: continue education } \\
\hline Yes continue education & $83 \%$ & & & & $43 \%$ & & & \\
\hline Total N & 31,594 & & & & 11,725 & & & \\
\hline
\end{tabular}

\section{Appendix C}

\section{See Table 5.}

Table 5 Descriptives of respondents in analysis on chance to get a job

\begin{tabular}{|c|c|c|c|c|c|c|c|c|}
\hline & \multicolumn{4}{|c|}{ No 'start qualification' } & \multicolumn{4}{|c|}{ 'Start qualification' } \\
\hline & Mean/pct & Std dev & Min & $\operatorname{Max}$ & Mean/pct & Std dev & Min & $\operatorname{Max}$ \\
\hline \multicolumn{9}{|l|}{ Demographics } \\
\hline Age & 18 & 1.86 & 16 & 30 & 21 & 2.27 & 17 & 30 \\
\hline Male & $48 \%$ & & & & $55 \%$ & & & \\
\hline Immigrant & $11 \%$ & & & & $10 \%$ & & & \\
\hline \multicolumn{9}{|c|}{ Sector of studies } \\
\hline General & $11 \%$ & & & & $0 \%$ & & & \\
\hline Agriculture & $35 \%$ & & & & $15 \%$ & & & \\
\hline Engineering & $19 \%$ & & & & $36 \%$ & & & \\
\hline Economics & $21 \%$ & & & & $37 \%$ & & & \\
\hline Healthcare & $15 \%$ & & & & $13 \%$ & & & \\
\hline
\end{tabular}


Table 5 continued

\begin{tabular}{|c|c|c|c|c|c|c|c|c|}
\hline & \multicolumn{4}{|c|}{ No 'start qualification' } & \multicolumn{4}{|c|}{ 'Start qualification' } \\
\hline & Mean/pct & Std dev & Min & $\operatorname{Max}$ & Mean/pct & Std dev & Min & $\operatorname{Max}$ \\
\hline \multicolumn{9}{|l|}{ Level of education } \\
\hline $\begin{array}{l}\text { Pre-vocational secondary } \\
\text { education }\end{array}$ & $82 \%$ & & & & & & & \\
\hline $\begin{array}{l}\text { Secondary vocational } \\
\text { education level } 1\end{array}$ & $18 \%$ & & & & & & & \\
\hline $\begin{array}{l}\text { Secondary vocational } \\
\text { education level } 2\end{array}$ & & & & & $100 \%$ & & & \\
\hline \multicolumn{9}{|l|}{ Category of studies } \\
\hline $\begin{array}{l}\text { Pre-vocational secondary } \\
\text { education }\end{array}$ & $82 \%$ & & & & $48 \%$ & & & \\
\hline Vocational training & $10 \%$ & & & & $52 \%$ & & & \\
\hline Apprenticeship training & $8 \%$ & & & & & & & \\
\hline \multicolumn{9}{|l|}{ Region } \\
\hline Population density $\mathrm{km}^{2}(\times 1000)$ & 0.74 & 0.49 & 0.17 & 2.46 & 0.62 & 0.45 & 0.17 & 2.46 \\
\hline Percentage economic growth & $5.9 \%$ & 2.4 & $-3.1 \%$ & $13.1 \%$ & $5.8 \%$ & 2.4 & $-3.1 \%$ & $13.1 \%$ \\
\hline Percentage unemployed 15-25 & $9.2 \%$ & 3.4 & $1.0 \%$ & $25.1 \%$ & $9.3 \%$ & 3.6 & $1.0 \%$ & $25.1 \%$ \\
\hline $\begin{array}{l}\text { Number of working people } \\
\text { with an elementary or } \\
\text { lower job }(\times 1000)\end{array}$ & 146.0 & 58.4 & 36.0 & 232.4 & 136.8 & 52.4 & 36.0 & 232.4 \\
\hline \multicolumn{9}{|l|}{ High educated } \\
\hline Oversupply high educated & 0.96 & 0.08 & 0.80 & 1.15 & 0.97 & 0.07 & 0.80 & 1.15 \\
\hline Percentage high educated & $26.6 \%$ & 5.9 & $16.7 \%$ & $42.1 \%$ & $25.8 \%$ & 5.6 & $16.7 \%$ & $42.1 \%$ \\
\hline \multicolumn{9}{|l|}{ Satisfaction } \\
\hline Choose same education & $34 \%$ & & & & $65 \%$ & & & \\
\hline Choose different education & $15 \%$ & & & & $23 \%$ & & & \\
\hline Not study at all & $5 \%$ & & & & $9 \%$ & & & \\
\hline Satisfaction unknown & $47 \%$ & & & & $2 \%$ & & & \\
\hline \multicolumn{9}{|l|}{ Dependent: Chance to get a job } \\
\hline Found a job & $85 \%$ & & & & $93 \%$ & & & \\
\hline Total N & 4283 & & & & 6282 & & & \\
\hline
\end{tabular}

\section{References}

Ashenfelter, O., Harmon, C., Oosterbeek, H.: Economic returns to schooling: new evidence. Labour Econ. 6(4), 453-470 (1999)

Autor, D.H., Levy, F., Murnane, R.J.: The skill content of recent technological change: an empirical exploration. Q. J. Econ. 118(4), 1279-1333 (2003)

Autor, D.H., Katz, L.F., Kearney, M.S.: The polarization of the US labor market. Am. Econ. Rev. 96(2), 189-194 (2006)

Bassanini, A., Duval, R.: Employment patterns in OECD countries: reassessing the role of policies and institutions. DELSA working paper no. 35, OECD, Paris (2006)

Becker, G.: Human Captial. A Theoretical and Empirical Analysis, with Special Reference to Education. National Bureau of Economic Research, New York (1964) 
Broersma, L., Edzes, A.J.E., Dijk, J. van: Human capital externalities and proximity: effects for lowskilled workers. Paper Presented at the 23rd Pacific Conference of the Regional Science Association International PRSCO, Bandung, Indonesia (2013)

De Grip, A., Wolbers, M.H.J.: Cross-national differences in job quality among low-skilled young workers in Europe. Int. J. Manpow. 27(5), 420-433 (2006)

Gesthuizen, M., Scheepers, P.: Economic vulnerability among low-educated europeans : resource, composition, labour market and welfare state influences. Acta Sociol. 53(3), 247-267 (2010)

Gesthuizen, M., Wolbers, M.H.J.: Employment transitions in the Netherlands, 1980-2004: are low educated men subject to structural or cyclical crowding out? Res. Soc. Stratif. Mobil. 28, 437-451 (2010)

Gesthuizen, M., Solka, H., Künster, R.: Context matters: economic marginalization of low-educated workers in cross-national perspective. Eur. Sociol. Rev. 27(2), 264-280 (2011)

Gobillon, L., Magnac, T., Selod, H.: The effect of location on finding a job in the Paris Region. J. Appl. Econom. 26(7), 1079-1112 (2011)

Goos, M., Manning, A.: Lousy and lovely jobs: the rising polarization of work in Britain. Rev. Econ. Stat. 89(1), 118-133 (2007)

Hair, J.F., Black, W.C., Babin, B.J., Anderson, R.E., Tatham, R.L.: Multivariate Data Analysis. Prentice hall, Upper Saddle River (2006)

Hensen, M.M., de Vries, M.R., Cörvers, F.: The Role of Geographic Mobility in Reducing EducationJob Mismatches in the Netherlands. Research Centre for Education and the Labour market (ROA), Maastricht (2009)

Josten, E.: Less Work for the Low-Skilled? Trends in Job Occupancy and Job Quality 1992-2008. The Netherlands institute for social research, The Hague (2010)

Layte, R., Maitre, B., Nolan, B., Whelan, C.T.: Persistent and consistent poverty in the 1994 and 1995 waves of the European community household panel survey. Rev. Income Wealth 47(4), 427-449 (2001)

Lopez-Bazo, E., Motellon, E.: The regional distribution of unemployment: what do micro-data tell us? Papers Reg. Sci. 92(2), 383-405 (2012)

Machid, S., Salvanes, K.G., Pelkonen, P.: Education and mobility. J. Eur. Econ. Assoc. 10(2), 417-450 (2011)

Moretti, E.: Workers' education, spillovers, and productivity: evidence from plant-level production functions. Am. Econ. Rev. 94(3), 656-690 (2004a)

Moretti, E.: Human capital externalities in cities. In: Henderson, J.V., Thisse, J.F. (eds.) Handbook of Regional and Urban Economics, vol. 4. Elsevier, Amsterdam (2004b)

Muffels, R., Fouarge, D.: The role of European welfare states in explaining resources deprivation. Soc. Indic. Res. 68, 299-330 (2004)

OECD: Education at a Glance 2011. OECD, Paris (2011)

Oesch, D., Rodríques Menés, J.: Upgrading or polarization? Occupational change in Britain, Germany, Spain and Switzerland, 1990-2008. Soc.-Econ. Rev. 9, 503-531 (2011)

Prevatt, F., Kelly, F.D.: Dropping out of school: a review of intervention programs. J. School Psychol. 41, 377-395 (2003)

Psacharopoulus, G., Patrinos, H.A.: Returns to investment in education: a further update. World bank policy research working paper 2881 (2002)

Quintini, G., Manfredi, T.: Going Separate Ways? School-to-Work Transitions in the United States and Europe. OECD, Paris (2009)

Sassen, S.: The Global City. Princeton University Press, New York, London, Tokyo (2001)

Spitz-Oener, A.: Technical change, job tasks, and rising educational demands: looking outside the wage structure. J. Labor Econ. 24(2), 235-270 (2006)

Tieben, N., Wolbers, M.H.J.: Transitions to post-secondary and tertiary education in the Netherlands: a trend analysis of unconditional and conditional social-economic background effects. Higher Educ. 60, 85-100 (2010)

Tsakloglou, P., Papadopoulos, F.: Aggregate level and determining factors of social exclusion in twelve European countries. Eur. Soc. Policy 12(3), 211-226 (2002)

van der Meer, P.H.: Is the gender wage gap declining in the Netherlands? Appl. Econ. 40, 149-160 (2008)

Venhorst, V.A., van Dijk, J., van Wissen, L.J.G.: An analysis of trends in spatial mobility of Dutch graduates. Spat. Econ. Anal. 6(1), 57-82 (2011)

Wolbers, M.H.J.: Patterns of labour market entry: a comparative perspective on school-to-work transitions in 11 European countries. Acta Sociol. 50(3), 189-210 (2007) 